\title{
PEMBERDAYAAN MASYARAKAT DESA KEPADA KELOMPOK IBU-IBU PKK DAN KARANG TARUNA MELALUI PROGRAM PELATIHAN "HIDROPONIK"
}

\author{
Ruswaji $^{1}$, Laely Chodariyanti ${ }^{2}$ \\ ${ }^{1,2}$ Jurusan Manajemen, Fakultas Ekonomi, Universitas Islam Lamongan \\ J1. Veteran No. 53 A \\ ruswaji1965@unisla.ac.id $^{1}$
}

\begin{abstract}
ABSTRAK
Berdasarkan analisis situasi diketahui bahwa sebagian besar ibu-ibu PKK warga desa Pelang, Kembangbahu, Lamongan berprofesi sebagai ibu rumah tangga, sehingga mempunyai waktu yang cukup banyak untuk melakukan kegiatan yang mampu menambah penghasilan. Tujuan dari program ini adalah untuk memberdayakan ibu rumah tangga dan karang taruna dengan memberi pelatihan bercocok tanam dengan sistem hidroponik. Konsep "Hidroponik" merupakan budidaya menanam dengan memanfaatkan air/larutan mineral bernutrisi tanpa menggunakan tanah dengan menekankan pada pemenuhan kebutuhan nutrisi. Sistem bertanam "Hidroponik" merupakan konsep bertanam yang cocok untuk daerah perkotaan dan lahan terbatas. Luaran jangka panjang yang diharapkan dari pengabdian ini adalah peningkatakan penghasilan dan peningkatan kesejahteraan. Guna mencapai target luaran yang telah direncanakan, kegiatan pengabdian dilakukan dengan tahapan sebagai berikut: (1) pemaparan materi "Hidroponik"; (2) Pelatihan kepada masyarakat dan Praktik Pembuatan "Hidroponik" dan (3) Pendampingan selama dua bulan atau praktik berkebun dengan sistem "Hidroponik" serta (4) Evaluasi kegiatan. Hasil dari pengabdian ini adalah terbentuknya kebun hidroponik yang ditempatkan di Kantor Balai Desa Pelang yang dikelola bersama antara Kelompok Ibu-ibu PKK dan Karang Taruna dan sangat respon dan antusias serta akan mengembangkannya di rumah masing-masing.
\end{abstract}

Kata Kunci : Hidroponik; Berkebun; Pemberdayaan Masyarakat; Peningkatan Perekonomian.

\begin{abstract}
Based on the situation analysis it is known that most of the PKK mothers from Pelang village, Kembangbahu Subdistrict, Lamongan Regency work as housewives, so they have ample time to carry out activities that are able to supplement their income. The purpose of this program is to empower housewives and youth by providing training in gardening with the hydroponic system. The concept of "Hydroponics" is the cultivation of plants using water/ nutrient mineral solutions without the use of soil by emphasizing the fulfillment of nutrition. This hydroponic farming system is a farming concept that is suitable for urban areas and limited land. The long-term outcome expected from this service is to increase income and welfare through hydroponics. In order to achieve the planned output targets, the service activities are carried out in the following stages: (1) presentation of "Hydroponics" material to provide understanding; (2) Training to the community and the Practice of Making "Hydroponics" and (3) Facilitation for two months on gardening practices with the "Hydroponics" system and (4) Evaluation of activities. The result of this dedication is the formation of a hydroponic garden which is placed in the Pelang Village Hall Office which is managed jointly by the PKK and Karang Taruna Women's Groups and is very responsive and enthusiastic and will develop it in their respective homes
\end{abstract}

Keywords: Hydroponics; Gardening; Community development; Economic Improvement. 


\section{PENDAHULUAN}

Desa Pelang merupakan sebuah Desa di Kecamatan Kembangbahu, Kabupaten Lamongan. Secara geografis Desa Pelang hanya berjarak kurang lebih $10 \mathrm{~km}$ dari kampus Universitas Islam Lamongan (UNISLA). Namun demikian, nampak bahwa masih terdapat kesenjangan perekonomian terutama antara warga asli Pelang dengan warga pendatang. Berikut adalah informasi terkait Desa Pelang. Pertanian merupakan sesuatu yang penting dalam perekonomian di wilayah Indonesia menurut muhtarom, abid (2018).

Tabel 1. Informasi Desa Pelang

\begin{tabular}{|c|l|c|}
\hline No & \multicolumn{1}{|c|}{ Keterangan } & Jumlah \\
\hline 1. & Jumlah KK & 1051 \\
2. & Jumlah RW & 5 \\
3. & Jumlah RT & 31 \\
4. & Jumlah Kelompok PKK & 1 \\
5. & Pertemuan PKK & 12 kali/tahun \\
6. & Jumlah Karang Taruna & 4 \\
7. & Pertemuan Karang Taruna & 12 kali/tahun \\
\hline \multicolumn{2}{|c|}{ Sumber : Data Desa Pelang 2018 } \\
\hline
\end{tabular}

Sebagian besar ibu-ibu warga Desa Pelang berprofesi sebagai ibu rumah tangga. Sehingga mereka mempunyai waktu yang cukup banyak untuk melakukan kegiatan yang mampu menambah penghasilan. Sebagian besar Ibu Rumah Tangga di Desa Pelang hanya mengandalkan dari penghasilan suami. Hanya sebagian kecil ibu rumah tangga di Desa Pelang yang memiliki pekerjaan sampingan seperti berjualan. Selama ini seusai menyelesaikan pekerjaan rumah seperti memasak, membersihkan rumah, mencuci, menyetrika dan lainnya biasanya mereka menonton televisi atau sekedar berbincang dengan tetangga. Jadi masih banyak waktu kosong yang belum dimanfaatkan secara optimal. Sementara kegiatan usaha untuk meningkatkan pendapatan ekonomi keluarga masih statis belum tergali potensi yang ada dilingkungan sekitarnya yang dapat meningkatkan pendapatan ekonomi keluarga. Atas kondisi tersebut melahirkan suatu ide untuk memberikan pelatihan/ pemberdayaan yang cocok dan sesuai bagi warga desa Pelang.

Pemberdayaan adalah keadaan yang terjadi atau hal-hal yang dilakukan dilingkungan masyarakat dengan upaya membangun pembangunan yang bertumpu pada masyarakat itu 
sendiri. Tujuan dari dilakukannya pemberdayaan masyarakat ini ialah untuk membuat masyarakat itu menjadi berdaya. Berdaya yang dimaksud di sini ialah upaya-upaya atau unsur-unsur yang memungkinkan masyarakat untuk bertahan dan mengembangkan diri untuk mencapai kemajuan, mandiri dan sejahtera. Maju yang di maksud ialah maju dalam hal ekonomi dan prekonomian seiring dengan majunya tingkat SDM. Dari uraian di atas tercermin peranan masyarakat itu sendiri yakni sebagai pelaku dan sasaran pemberdayaan dari berbagai sektor, serta peranan pemerintah maupun lembaga pendidikan yaitu sebagai vasilitator agar terwujud masyarakat yang berdaya.

Untuk mencapai kemandirian warga di Desa Pelang, maka potensi yang ada perlu digali. Kondisi yang telah diuraikan diatas menunjukkan bahwa ibu-ibu yang tergabung dalam gerakan PKK serta Karang Taruna sebagai generasi penerus memiliki potensi besar untuk diberdayakan. Adapun pemberdayaan yang akan dilakukan adalah dengan memberikan pelatihan mengenai Hidroponik. Pemilihan pemberdayaan masyarakat dengan memberi pelatihan Hidroponik dengan alasan sebagai berikut: (1) Sebagian besar ibu-ibu dan Karang Taruna di desa Pelang tidak memiliki pekerjaan sampingan bahkan juga menganggur, sehingga bercocok tanam dengan Hidroponik dapat menghasilkan untuk meningkatkan perekonomian keluarga. (2) Bercocok tanam dengan Hidroponik tidak membutuhkan lahan luas, cukup dilakukan dihalaman sekitar rumah. (3) Bercocok tanam dengan Hidroponik mudah dilakukan tanpa harus pergi jauh dari rumah sehingga tidak mengganggu pekerjaan rutin dirumah. (4) Setiap hari warga membutuhkan sayuran untuk dikonsumsi, selama ini warga membeli sayuran tersebut dari pasar atau penjual keliling. Apabila warga menanam sayuran sendiri maka bisa menghemat pengeluaran. (5) Barang-barang bekas yang tak bernilai bisa dimanfaatkan sebagai media dalam bercocok tanam dengan Hidroponik sehingga meningkatkan nilai barang bekas.

\section{METODE}

Untuk mencapai target luaran yang telah direncanakan, program ini dilakukan melalui tahapan sebagai berikut:

\section{Pemaparan Materi}

Metode yang digunakan dengan memakai teknik ceramah interaktif dengan media power point. Adapun materi yang diberikan yaitu: (a) Pentingnya pemberdayaan ibu rumah tangga dan Karang Taruna, (b) Pemanfaatan barang bekas, Pengertian Hidroponik, (d) 
Kelebihan Hidroponik, (e) Pengadaan media tanam Hidroponik, (f) Jenis Tanaman Hidroponik untuk di rumah, (g) Pemeliharaan tanaman Hidroponik, (h) Pemanenan Hidroponik.

\section{Praktik Pembuatan Hidroponik}

Setelah seluruh warga memahami materi tentang hidroponik, selanjutnya adalah mempraktekkan untuk membuat hidroponik. Praktek yang telah terlaksana adalah pembuatan hidroponik yang menggunakan media peralon. Hidroponik ini yang selanjutnya akan dijadikan kebun bagi Kelompok Ibu-ibu PKK dan Karang Taruna Desa Pelang Kecamatan Kembangbahu. Menurut Lingga (2006) dan Roberto (2005) bahan yang dapat digunakan untuk membuat hidroponik adalah sebagai berikut: (a) Paralon besar putih; (b) Peralon kecil putih; (c) Penyambung pipa abu-abu; (d) Ember penampung air; (e) Pompa air; (f) Atap mika bening; (g) Gelas tempat tanaman; (h) Kain flanel; (i) Rockwol; (j) Nutrisi; (k) Benih.

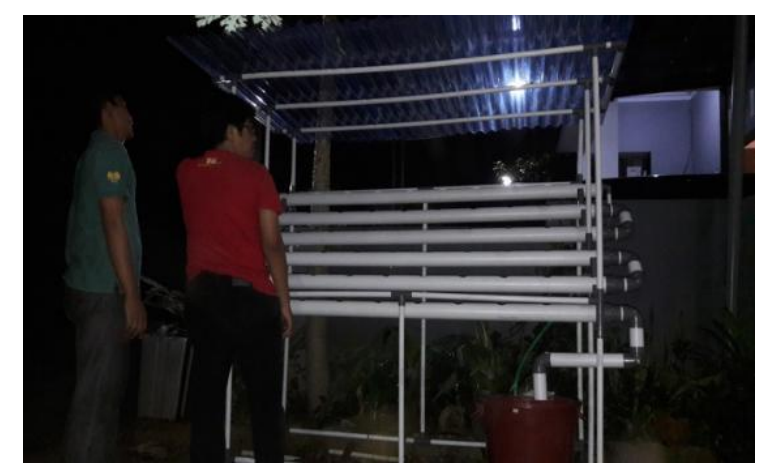

Gambar 2: Kebun Hidroponik

Adam, et. al (2015) dan Istiqomah (2015) mengemukakan cara yang dapat diterapkan dalam penanaman hidropinik sangat sederhana, yaitu sebagai berikut: (1) Bibit disemai pada media rockwol, (2) Bibit yang sudah tumbuh (kira-kira butuh waktu seminggu), (3) Masukan bibit sayuran ke dalam lubang tanam, media tanam memakai Rockwool yang telah ditaruh didalam gelas dan diberi kain flanel sebagai sumbu untuk mengalirkan air dan nutrisi, (4) Isi bak penampung dengan nutrisi sesuai takaran, (5) Tambah air dan nutrisi setiap minggu, (6) Tunggu hingga tanaman siap dipanen. 


\section{Pendampingan}

Untuk memastikan bahwa program dapat berjalan sesuai dengan yang diharapkan, maka tahapan berikutnya yang dijalankan adalah pendampingan. Selama 2 bulan tim pengabdian kepada masyarakat mendampingi serta memantau pelaksanaan program pemberdayaan masyarakat melalui pelatihan Hidroponik ini. Selain pendampingan secara fisik datang langsung, juga dilakukan melalui kontak telephone maupun pesan singkat (sms) karena cara tersebut dirasa lebih efektif dan efisien jika dalam praktek dilapangan mengalami kesulitan.

\section{Evaluasi Kegiatan}

Untuk mengetahui keberhasilan dari kegiatan ini maka evaluasi dilakukan dengan cara sebagai berikut: (a) Kegiatan pemaparan materi dievaluasi berdasarkan partisipasi peserta serta keaktifan peserta. Apabila tingkat partisipasi minimal mencapai $60 \%$ dari seluruh peserta yang direncanakan maka kegiatan ini dianggap berhasil. Keaktifan peserta dan keefektifan pemaparan dinilai dari interaksi peserta selama pelaksanaan pemaparan materi. (b) Evaluasi utama atas pengabdian ini adalah apabila target dari program ini tercapai yaitu setiap warga memiliki Hidroponik dirumah masing-masing. Adapun kegiatan pengabdian dianggap berhasil apabila minimal terdapat 15 warga yang berhasil membuat Hidroponik.

\section{HASIL DAN PEMBAHASAN}

Konsep Hidroponik merupakan sistem budidaya pertanian yang dilakukan secara horizontal, baik dalam ruangan maupun diluar ruangan dengan media utama air (Mas'ud, 2009). Sistem budidaya pertanian secara hidroponik ini merupakan konsep penghijauan yang cocok untuk daerah perkotaan dan lahan terbatas (Tom, 2005). Murali et al. (2011) juga menyampaikan bahwa dilihat dari sisi ekonomi, menanam sayuran dengan konsep Hidroponik sangat menguntungkan. Tanpa membutuhkan biaya yang tinggi dan dengan perawatan yang relatif mudah (Tallei dkk, 2017) warga bisa memenuhi kebutuhan sayur mayur sehat tanpa harus membeli.

Kegiatan pengabdian kepada masyarakat ini terbagi menjadi 2 program besar yaitu kegiatan pelatihan guna penyampaian materi terkait hidroponik dan program praktik pembuatan hidroponik. Adapun penjelasan masing-masing kegiatan adalah sebagai berikut. 


\section{Kegiatan Pelatihan}

Kegiatan pelatihan dimaksudkan untuk memberikan pemahaman kepada target sasaran masyarakat terkait cara penanaman hidroponik. Adapun kegaitan pelatihan telah dilaksankan selama 2 kali sebagai berikut:

\section{Pelatihan Kepada Ibu-ibu PKK dan Karang Taruna}

Pelatihan dilakukan terhadap ibu-ibu Anggota PKK dan Karang Taruna Desa Pelang Adapun materi yang diberikan adalah sebagai berikut: (a) Pentingnya pemberdayaan ibu rumah tangga dan Karang Taruna;(b) Pengertian Hidroponik; (c) Kelebihan Hidroponik; (d) Pengadaan media tanam Hidroponik; (e) Jenis Tanaman Hidroponik untuk di rumah; (f) Pemeliharaan tanaman Hidroponik; (g) Pemanenan Hidroponik. Kegiatan pelatihan kepada seluruh warga dengan narasumber Sdr. Reynaldi. Peserta dalam kegiatan ini sebanyak 20 orang ibu-ibu PKK sebanyak 15 orang dan Karang Taruna sebanyak 5 orang. Kebun hidroponik yang ditanami sayuran berupa Selada Putih dan Selada Merah dan Kangkung di lahan kebun Balai Desa.

\section{Pembahasan}

Praktik menanam sayuran dengan metode hidroponik di Desa Pelang mendapat respon positif dari warga terutama yang berprofesi sebagi ibu rumah tangga. Secara umum metode hidroponik yang dijalankan adalah persiapan bibit, penanaman, pemeliharaan tanaman dan pemanenan.

\section{Persiapan Bibit Tanaman dan Penanaman}

Seperti halnya menanam, menyemaikan benih juga memerlukan wadah dan media tanam. Wadah bisa apa saja sepanjang dapat diisi media tanam seperlunya dan memiliki lubang di bagian bawah untuk mengeluarkan kelebi-han air. Persemaian menggunakan wadah khusus persemaian benih yang disebut tray. Dapat juga persemain menggunakan sebuah pot ukuran sedang dan sebuah bekas tempat kue. Adapun untuk media tanamnya adalah media tanam dari produk jadi yang bersifat organik. 


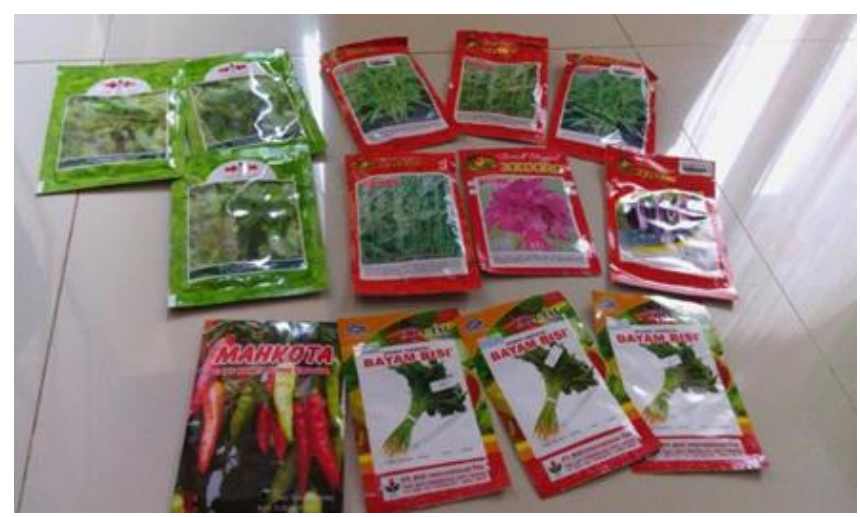

Gambar 4: Benih untuk Hidroponik

\section{Pemeliharaan Tanaman}

Tanaman juga memerlukan perawatan, seperti halnya makhluk hidup yang lain. Tanaman memerlukan perhatian dan kasih sayang. Selain penyiraman dilakukan setiap hari juga perlu pemupukan, dan juga pengendalian hama penyakit.

\section{Pemanenan}

Pemanenan sayuran biasanya dilakukan dengan sistem cabut akar (sawi, bayam, seledri, kemangi, selada, kangkung dan seb-againya). Apabila kita punya tanaman sendiri dan dikonsumsi sendiri akan lebih menghemat apabila panen dilakukan dengan mengambil daunnya saja. Dengan cara tersebut tanaman sayuran bisa bertahan lebih lama dan bisa panen berulang-ulang.

Sebagian besar ibu-ibu warga Desa Pelang berprofesi sebagai ibu rumah tangga. Sehingga mereka mempunyai waktu yang cukup banyak untuk melakukan pekerjaan lain. Selama ini seusai menyelesaikan pekerjaan rumah seperti memasak, membersihkan rumah, mencuci, menyetrika dan lainnya biasanya mereka menonton televisi atau sekedar berbincang dengan tetangga. Hanya sebagian kecil ibu rumah tangga yang memiliki pekerjaan sampingan seperti berjualan. Sehingga ide untuk memberikan pelatihan Hidroponik sangat cocok bagi warga Desa Pelang.

Pelatihan penanaman pada lahan terbatas tersebut direspon positif oleh Kelompok Ibuibu PKK dan Karang Taruna Desa Pelang. Pelatihan pertama difokuskan kepada Ibu-ibu dan Karang Taruna. Hal tersebut dengan pemikiran karena Kelompok Ibu-ibu PKK dan Karang Taruna anggotanya sebagian besar adalah berpendidikan SMA dan Sarjana. Dengan demikian Kelompok Ibu-ibu PKK dan Karang Taruna ini yang nantinya akan menjadi mentor bagi 
anggota lainnya di Desa Pelang. Adapun hasil dari kegaitan pengabdian ini adalah adanya kebun hidroponik untuk warga yang dikelola dan hasilnya juga dimanfaatkan untuk warga sendiri. Selain itu setiap anggota PKK dan Karang Taruna Desa Pelang berencana akan menaman hidroponik. Sambutan warga sangat tertarik menerima penjelasan dari pembicara. Seluruh angota Kelompok Ibu-ibu PKK juga antusias untuk mempraktekkan cara bercocok tanam tersebut.

\section{SIMPULAN}

Hidroponik adalah budidaya menanam dengan memanfaatkan air /larutan mineral bernutrisi tanpa menggunakan tanah dengan menekankan pada pemenuhan kebutuhan nutrisi bagi tanaman. Kegiatan pelatihan dan praktik pembuatan hidroponik telah dilaksanakan. Adapun hasil dari pengabdian ini adalah warga memahami cara bertanam Hidroponik serta mampu mempraktekannya. Hasil dari program ini terbentuk kebun hidroponik di Balai Desa Pelang Kecamatan Kembangbahu, Kabupaten Lamongan dan Kelompok Ibu-ibu dan Karang Taruna sangat antusias dan akan mengembangkannya di rumah masing-masing serta akan menyebarkan kepada warga Ibu-ibu dan pemuda yang lain.

\section{DAFTAR PUSTAKA}

Muhtarom,Abid. 2018. Subsisdi Of Fertilizers, Government Expenditure, Level Of Education, Ratio Of Range And Land For Agricultural Production (District Agricultural Studies - East Java 2010-2016 With Robust Test Method Analysis LAD Least Absolout Deviation). MediaTrend 13 (1) 2018 p. 82-89, http://journal.trunojoyo.ac.id/mediatrend

Adam, C.R., Early, M.P., Brook, J.E., Bam-ford, K.M. 2015. Principle of Horticulture. Routledge: London.

Istiqomah, S. 2015. Menanam Hidroponik. Ganeca Exact: Bekasi.

Lingga, P. 2006. Hidroponik, Bercocok Tanam Tanpa Tanah. Penebar Swadaya: Depok.

Mas'ud, H. 2009. Sistem Hidroponik den-gan Nutrisi dan Media Tanam Berbe-da Terhadap Pertumbuhan dan Hasil Selada. Media Litbang Sulteng. 2 (2), 131- 136.

Murali, M.R., Soundaria, M., Maheswari, V., Santhakumari, P., Gopal, V. 2011. Hydroponics, a novel alternative for geo-ponic cultivation of medicinal plants and food crops. International Journal Pharmacy and Biology Science, 2(2), 286-296.

Roberto, K. 2005. How to Hydroponics. Harvard University: Futuregarden Inc. London. 
Abdimas Berdaya: Jurnal Pengabdian Masyarakat

Vol. 2 No. 1 (2019)

P-ISSN: 2685-1563

Tallei, T.E., Rumengan, I.F.M., dAdam, A. 2017. Hidroponik untuk Pemula. Penerbit LPPM Universitas Lambung Mangkurat, UNSRAT PRESS: Banjar-masin.

Tom, T. 2005. Garden History : Philosophy and Design, 2000 BC--2000 AD. Spon Press; New York. 